\title{
Contribution to Early Holocene vegetation and climate history of Eastern Orinoco Llanos, Venezuela, from a paleoecological record of a Mauritia L.f. swamp
}

\author{
Alejandra LEAL ${ }^{1}$, Tibisay PEREZ ${ }^{2}$, Bibiana BILBAO ${ }^{1}$
}

\begin{abstract}
A palynological analysis of an organic paleosol found at 150-125 cm depth in a Mauritia swamp from the Eastern Orinoco Llanos is presented. The $25 \mathrm{~cm}$ pollen record summarizes the vegetation history during the Early Holocene, from 10,225 to 7,800 calendar yr BP. The vegetation was characterized by a Poaceae marsh, where Asteraceae, Melastomataceae, Schefflera-type and Phyllanthus were the most abundant shrubs and trees. Pollen-types richness was lower than that recorded today in similar environments, and Mauritia pollen was absent. Results suggest that climate was as humid as present during the beginning of the Holocene, with a decreasing trend in humidity from around 8,000-7,000 yr BP, in coincidence with the beginning of the "Early-Mid-Holocene Dryness" that affected deeply the Amazon Basin and neighboring areas. Dry climatic conditions could have existed in the study site until the Mid-Late Holocene when a Mauritia swamp developed, and humid conditions similar to present established. Main climate phases inferred in our study site fit well with regional trends recorded in other places located north Amazon Basin. However, conclusions are still limited by the lack of additional Quaternary records in the Orinoco Llanos area, avoiding regional correlations.
\end{abstract}

KEYWORDS: Orinoco Llanos, Mauritia swamp, Early Holocene, paleoclimate, Early-Mid Holocene Dryness.

\section{Contribuição para a história da vegetação e clima durante o Holoceno Temprano do Llanos Orientais do Orinoco, Venezuela, a partir de um registro paleoecológico de um pântano Mauritia L.f.}

\section{RESUMO}

Realizou-se uma análise de pólen amostrada em paleossolos orgânicos, entre 150-125 cm de profundidade, em um pântano Mauritia os lhanos do Orinoco. O registro de pólen dessa amostra resumiu a história da vegetação durante o Holoceno Temprano, entre 10,225-7,800 cal. anos AP. A vegetaçáo durante esse período foi caracterizada por um pântano de Poaceae, com maior abundância de arbustos e árvores de Asteraceae, Melastomataceae, tipo-Schefflera e Phyllanthus. Encontrou-se que a riqueza de tipos polínicos no Holoceno Temprano foi menor do que a riqueza atualmente encontrada em ambientes similares; o pólen de Mauritia esteve ausente de todas as amostras. Os resultados deste estudo sugerem que o clima durante o início do Holoceno foi úmido, semelhante ao clima atual. Houve também uma tendência de diminuição de umidade entre 8,000-7,000 anos AP, o que coincidiu com o início da "seca do Holoceno Temprano-Médio". Esta seca afetou profundamente a Bacia Amazônica e áreas adjacentes, persistindo no local de estudo até o Holoceno Médio-Final, período em que surgiram o pântano Mauritia e as condiçôes climáticas atuais. Fases climáticas principais deduzidas se encaixam bem com as tendências regionais registradas em outros lugares localizados ao norte da Bacia Amazônica. No entanto, as conclusóes ainda são limitadas pela falta de novos registros quaternários na área lhanos do Orinoco, evitando correlaçóes regionais.

PaLAVRAS-CHAVE: lhanos do Orinoco, Mauritia pântano, Holoceno Temprano, paleoclima, seca do Holoceno Temprano-Médio.

\footnotetext{
${ }^{1}$ Laboratorio de Dinámica de Comunidades y Procesos Ecológicos. Departamento de Estudios Ambientales. Universidad Simón Bolívar. Carretera Hoyo de la Puerta-Baruta, Sartenejas, Edo. Miranda, Venezuela. AP 89000. Fax.+0582129063039. E-mail: aveleal@yahoo.com, bbilbao@usb.ve.

2 Laboratorio de Química Atmosférica. Instituto Venezolano de Investigaciones Científicas. Altos de Pipe, Km 14, Carretera Panamericana, Edo. Miranda, Venezuela. E-mail: tperez@ivic.gob.ve.
} 


\section{INTRODUCTION}

The Quaternary history of Neotropical savannas is still poorly understood, particularly in the Llanos region, although it represents the largest continuous savanna area in northern South America. Until now only a few Quaternary pollen records have been analyzed for the entire region, all of them at the westernmost part, known as Llanos Orientales of Colombia (Behling and Hooghiemstra 2001; Wille et al. 2003). No pollen record for the Venezuelan part of the Llanos, known as Llanos del Orinoco existed until now.

The available data from the Llanos Orientales of Colombia, suggest the occurrence of arid and semi-arid periods during Late Pleistocene (Behling and Hooghiemstra 1999), Early and Middle Holocene (Behling and Hooghiemstra 1998), which deeply affected the dynamic of forest-savanna transitions (Behling and Hooghiemstra 2001; Berrío et al. 2002; Wille et al. 2003). Furthermore, the occurrence of extremes climates which had a substantial impact on vegetation and landscape is supported by the presence of paleodune fields in the Western Venezuelan Llanos, dated at 36,000 and 11,600 year before present (hereafter abbreviated as yr BP) (Roa 1979; Vaz and García-Miragaya 1989, location shown in Figure 1), and the sodic alluvial soils dated at 8,700 to $4,000 \mathrm{yr} \mathrm{BP}$, found in the central Venezuelan Llanos (Vaz and García-Miragaya 1992, location shown in Figure 1). Fossil dunes, as well as sodic soils could have been shaped during very arid periods, when strong changes on annual rainfall, maybe synchronous with glacial/interglacial cycles and with the Pleistocene/Holocene boundary occurred (Hooghiemstra and Van der Hammen 1998). However, paleoecological evidences about Quaternary climates at the Venezuelan part of the Orinoco Llanos are weak, due to the fragmented character of available studies, and the absence of any reliable indicator of past vegetational dynamic in such studies.

The unexplored nature of the Orinoco Llanos paleovegetation, together with the tendency of Mauritia palm swamps to be favorable environments for pollen and spores preservation, as well as the sensitivity of these communities to changes in rainfall regimes, motivated us to choose such communities to conduct a paleoecological study, whose main results are shown next. The palynological analysis of a $10,225 \mathrm{cal}$. (calibrated) yr BP organic paleosol presented here constitutes the first contribution to the Holocene vegetational history of the Venezuelan part of this large and important savanna area.

\section{MATERIAL AND METHODS}

\section{Environmental Settings}

The study site is a 3-Km long Mauritia swamp, called "morichal Mapire" located in a flat valley next to the plateau "Mesa de Urica" (9 $33^{\circ} \mathrm{N}, 63^{\circ} 40^{\prime} \mathrm{W}, 80 \mathrm{~m}$ asl), in

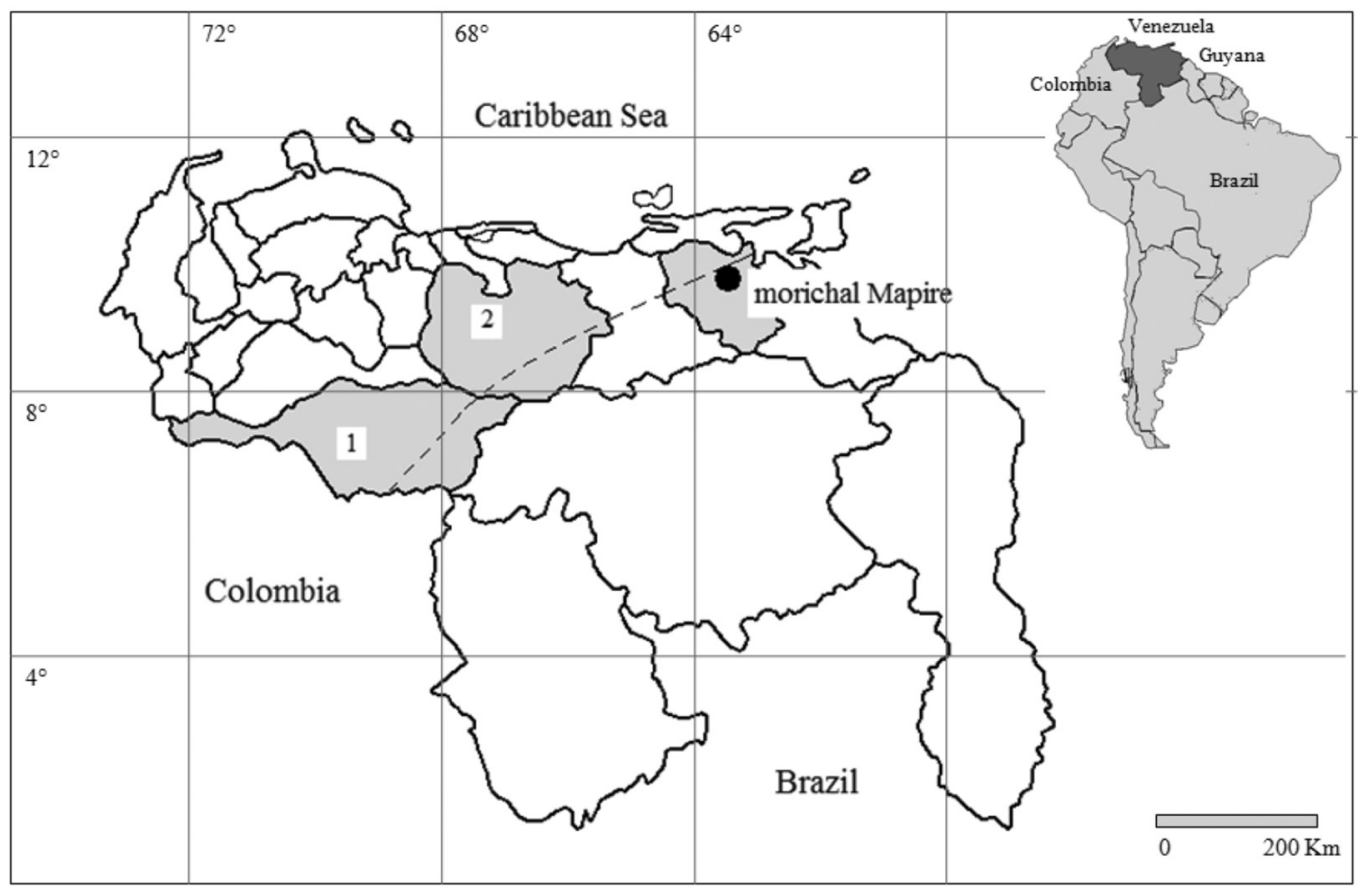

Figure 1 - Relative location of morichal Mapire at Eastern Orinoco Llanos, Monagas State, Venezuela. The northernmost edge of current distribution of Mauritia flexuosa is shown (dotted line, according to Rull, 1998). The location of paleodune fields in Apure State (1), and sodic alluvial soils in Guárico State (2) are also shown (after Roa, 1979; Vaz and García-Miragaya, 1989, 1992). 
Venezuela's Eastern Llanos (Figure 1). The site represents a so called "closed morichal" (according to the structural classification by González 1987), with Mauritia flexuosa L.f. as the dominant element, accompanied by several herbs (Poaceae, Cyperaceae, Onagraceae, Araceae, etc.), pioneer shrubs and trees (Melastomataceae, Asteraceae, Araliaceae, Cecropia, etc.), and even some gallery forest trees and palms. The study site was bordered by the main vegetation matrix characteristic of Eastern Venezuelan Llanos, which is made up by Trachypogon spicatus savannas with typical savanna trees: Curatella americana, Byrsonima crassifolia, and also some woody legumes (Aristeguieta 1968; Monasterio and Sarmiento 1970; González 1987; Duno et al. 2007). Current climate is seasonal, with $26-27^{\circ} \mathrm{C}$ of mean temperature and monthly oscillation less than $2^{\circ} \mathrm{C}$. Mean annual rainfall is about 1,125 $\mathrm{mm}$, with a dry season that lasts from November until May, and brings along a pronounced water deficit (Colonello et al. 1983). July is the month with the highest precipitation in concordance with the northernmost migration of the Intertropical Convergence Zone (ITCZ). However, despite the strong seasonality of rainfall observed in the region, surface soils of morichal Mapire are water saturated even during the dry season, which is a pre-requisite for the occurrence of Mauritia flexuosa palms (González 1987).

\section{Sampling and Pollen Analysis}

Paleoecological reconstruction was made from a core sampled in morichal Mapire, which will hereafter be called "Mapire core". The sampling was done with a "vibracore" sampler (Lanesky et al. 1979; Smith 1984). Texture characterization of core strata was made through Bouyoucos method (Casanova 1994), and total organic carbon determination through digestion with a sulfuric acid-potassium dichromate mixture (Anderson and Ingram 1993). Three bulk samples were prepared at the Stable Isotope Laboratory, University of California (Irvine), and radiocarbon dates determined at the Center for Accelerator Mass Spectrometry, Lawrence Livermore National Laboratory, USA. Continuous $2 \mathrm{~cm}^{3}$ sediment samples were taken for pollen analysis. Standard methods of acetolysis, removal of silicates and humic acids were used for sample preparation (Faegri and Iversen 1981). Lycopodium tablets were added to samples before preparation to estimate palynomorphs concentration.

Slides to quantify palynomorphs abundance were prepared with a glicerin-glicerinated gelatin mixture and then counted in a light microscope at 400 and 1000x. At least 300 pollen grains of terrestrial taxa were counted for most samples. Pollen was identified as Family or Genera level, and spores classified into types by the use of pollen atlases (Tschudy and Tschudy 1965; Herrera and Urrego 1996; Colinvaux et al. 1999, Bush and Weng 2007), and comparison with reference slides made by the authors with material from the National Herbarium of
Venezuela (VEN). The pollen data are presented as percentages of the terrestrial pollen sum that includes all pollen sourced from terrestrial taxa which in turn included gallery forest, Mauritia swamps and savanna communities. Cyperaceae is a family largely associated with high humidity conditions and hence considered in many paleoecological studies as an azonal taxon (because it depends on high humidity conditions). However in our study site sedges represent an important component of savanna communities and then their pollen was considered together with terrestrial taxa. The pollen of aquatic plants and fern spores was excluded from the pollen sum since it is not a component of terrestrial communities studied here, but it is an important indicator of hydrological conditions so it was treated separately. Fungi and algae remains were also analyzed separately because their abundance is not comparable with that exhibited by pollen or fern spores. Ecological groups were then further classified into: a) gallery forest shrubs, trees and lianas, b) savanna herbs, shrubs and trees, c) aquatic plants, d) ferns spores, and e) fungi and algae spores and remains. The abundance of each individual taxon and that of ecological groups is shown in pollen diagrams plotted with PSIMPOLL 4.10, PSCOMB 1.04 free software by Keith Bennett (available at: http://www.chrono.qub. ac.uk/psimpoll/psimpoll.html). Calibration of radiocarbon dates was made with CALIB 5.01 free software by Stuiver and Reimer, 1996-2005, and depth-age interpolations were done on a linear regression model of calibrated radiocarbon dates vs. depth.

\section{RESULTS}

\section{Stratigraphy and Chronology}

The Early Holocene section that represents the main subject of this paper was found buried between 150-125 $\mathrm{cm}$ deep in a peat and clay core (Mapire core) that had a total length of $160 \mathrm{~cm}$ in depth. Soil organic carbon (SOC) concentration and stratigraphy of the whole core is illustrated in Figure 2 and comprehended four strata (C, A2, B and A1). Soil organic carbon (SOC) is also shown in Figure 2, and it was minimal at $\mathrm{C}$ level, where neither pollen or spores, nor plant remains were found. An unexpected increase of SOC to around 20\% was observed at A2 level, representing twice those observed in surface peat (Figure 2). Plant remains and charcoal could only be observed through the microscope (not with the naked eye), but palynomorphs exhibited notably high concentrations (around 500,000 grains $\mathrm{cm}^{-3}$ ). This was followed by a steady decrease in SOC for level B where neither palynomophs, nor plant remains were preserved. SOC increased again in level A1 to values around $10 \%$ to $6 \%$. In this level pollen and spores concentration was high (>200,000 grains $\mathrm{cm}^{-3}$ ), and charcoal particles and plant remains were abundant, and observable with the naked eye. 


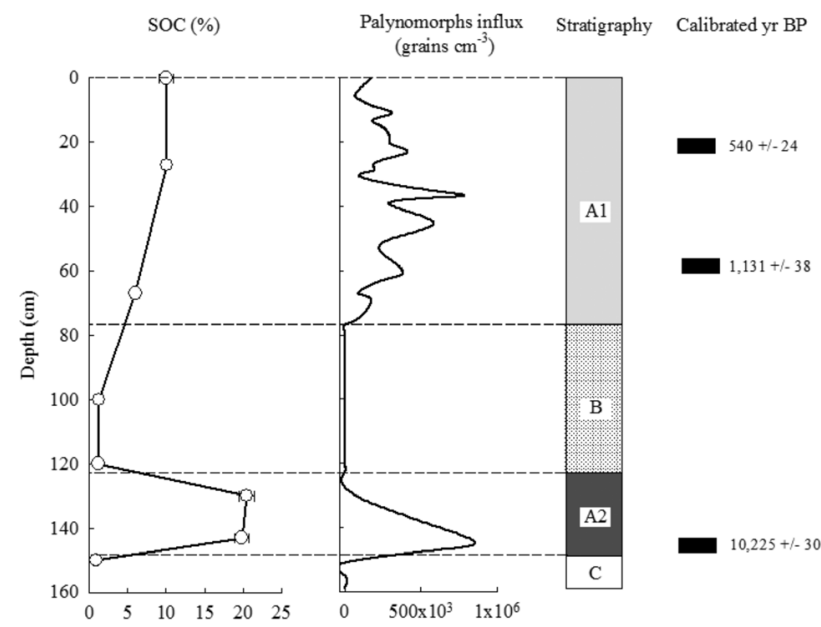

Figure 2 - Stratigraphy of Mapire core. Concentration (\%) of soil organic carbon (SOC) vs. depth, total pollen and spores influx, and the four distinctive strata observed with the calibrated radiocarbon dates are shown. $C=(160-145$ $\mathrm{cm})$, yellow orange spotted fine clay, no organic remains observed. $\mathrm{A} 2=$ $(145-125 \mathrm{~cm})$, black peat paleosol, Mauritia pollen is absent. $B=(125-75$ $\mathrm{cm})$, grey-white spotted fine clay, without plant remains, either pollen or spores. $A 1=(75-0 \mathrm{~cm})$, brown to dark peat with many charcoal particles and plant remains. Mauritia pollen exhibits a continuous record in this stratum. See text to further details.

Texture was clayey ( $64.5 \%$ clay, $24.4 \%$ silt and $12.8 \%$ sand) and homogeneous along the core.

The three bulks dated (Figure 2 and Table 1) were indicate that sedimentation had probably been sequential, and sediments were deposited during Early Holocene time. Level A2 covers the vegetation history of most Early Holocene, from 10,225 until 7,800 interpolated yr BP, while level B was deposited between 7,800 and 2,200 interpolated yr BP, and $\mathrm{A} 1$ encompasses the last 2,200 $\mathrm{yr} \mathrm{BP}$ with a continuous pollen record.

Pollen preservation occurred in strata $\mathrm{A} 2$ and $\mathrm{A} 1$, but not in strata B and C (Figure 2). The lack of pollen in stratum B bears witness to the fact that pollen records of levels A2 and A1 must have been separated by a time gap of at least 5,000 yr. Hence there is no continuity between $\mathrm{A} 2$ and $\mathrm{A} 1$ pollen

Table 1 - AMS radiocarbon dates and calibrated dates. The depth of samples and $d^{13} \mathrm{C}$ values are also shown.

\begin{tabular}{lccccc}
\hline Sample & $\begin{array}{c}\text { Depth } \\
(\mathrm{cm})\end{array}$ & ${ }^{13} \mathrm{C} /{ }^{12} \mathrm{C}$ & ${ }^{14} \mathrm{C}$ & ${ }^{14} \mathrm{C}$ yr BP & $\begin{array}{c}\text { Calibrated } \\
\text { Age (yr BP) }\end{array}$ \\
\hline 1 & $143-147$ & -26.99 & $-31.8(1.8)$ & $9,070(45)$ & $10,225(30)$ \\
2 & $63-67$ & -20.91 & $-169.8(3.4)$ & $1,445(35)$ & $1,331(38)$ \\
3 & $23-27$ & -22.85 & $-71.2(4.3)$ & $545(40)$ & $540(24)$ \\
\hline
\end{tabular}

records, and palynological analysis has shown that actually both pollen assemblages corresponded to two very different communities. The time distance and the observed differences in pollen assemblages of both pollen records $\mathrm{A} 2$ and $\mathrm{A} 1$ justify a separate analysis of each one.

In the next section we present the results of a paleoecological analysis carried out at level A2, which is of relevance to Early Holocene history of Eastern Orinoco Llanos and will be described in detail. The pollen diagram of level A1 of Late Holocene times is also shown and discussed shortly because it is of great relevance for paleoclimatic reconstructions, giving likewise a broad perspective that allows a better interpretation of Early Holocene paleoflora. A detailed description of level $\mathrm{A} 2$ is given in Leal and Bilbao (in press).

\section{Description of Pollen Diagrams}

Pollen diagram of level A2 is shown in Figure 3. This pollen assemblage is characterized by the presence of low pollen type richness and the strong dominance of Poaceae along the entire record. Savanna herbs (mainly represented by Poaceae and Cyperaceae) reached almost $90 \%$ of the pollen sum, and pioneer taxa: Asteraceae, Melastomataceae, Schefflera-type and Phyllanthus were the most abundant shrubs and trees. Although dominant pollen types had a more or less homogeneous abundance, a local event divides the record in three zones that could be related with major changes in hydrological conditions (Figure 3): i) A first zone that includes from 147 to $143 \mathrm{~cm}(10,225$ to 9,800 interpolated yr BP), with 76\% Poaceae, 18\% Cyperaceae, and the absence of aquatics. Arboreal pollen is also scarce, with the exception of Clusia, which reaches 2\%. Scheffleratype and Cestrum appeared later with values under $1 \%$. Melastomataceae, Asteraceae and Caesalpiniaceae were the best represented dicots, with percentages around 2 or $3 \%$, but in general very low pollen type richness was observed. Ferns were represented mainly by monolete psilate, and monolete verrucate, both maybe belonging to Polypodium genera. Fungi and algae were around 180,000 and 60,000 grains $\mathrm{cm}^{-3}$, respectively. ii) A second zone from 145 to 131 $\mathrm{cm}(9,800$ to 8,900 interpolated yr BP), where Poaceae pollen decreased to $40 \%$, Cyperaceae was between 18 and 25\%, and pollen type richness increased slightly. Also there was an increase in Schefflera-type, Cecropia, Moraceae/Urticaceae, Asteraceae, Miconia, other Melastomataceae, and Phyllanthus. Some gallery forest taxa were represented as well, such as Macrolobium, EuterpelGeonoma, Dilleniaceae, Protium and Bignoniaceae. All arboreal taxa together reached more than $17 \%$. Richness was also higher within savanna herbs group, due to the occurrence of Lamiaceae, Borreria and Polygala. Also, aquatics were present; with Hydrocotyle, Polygonum and Ludwigia. Amaranthaceae/Chenopodiaceae occurred, and reached its highest abundance. Fern richness also increased 


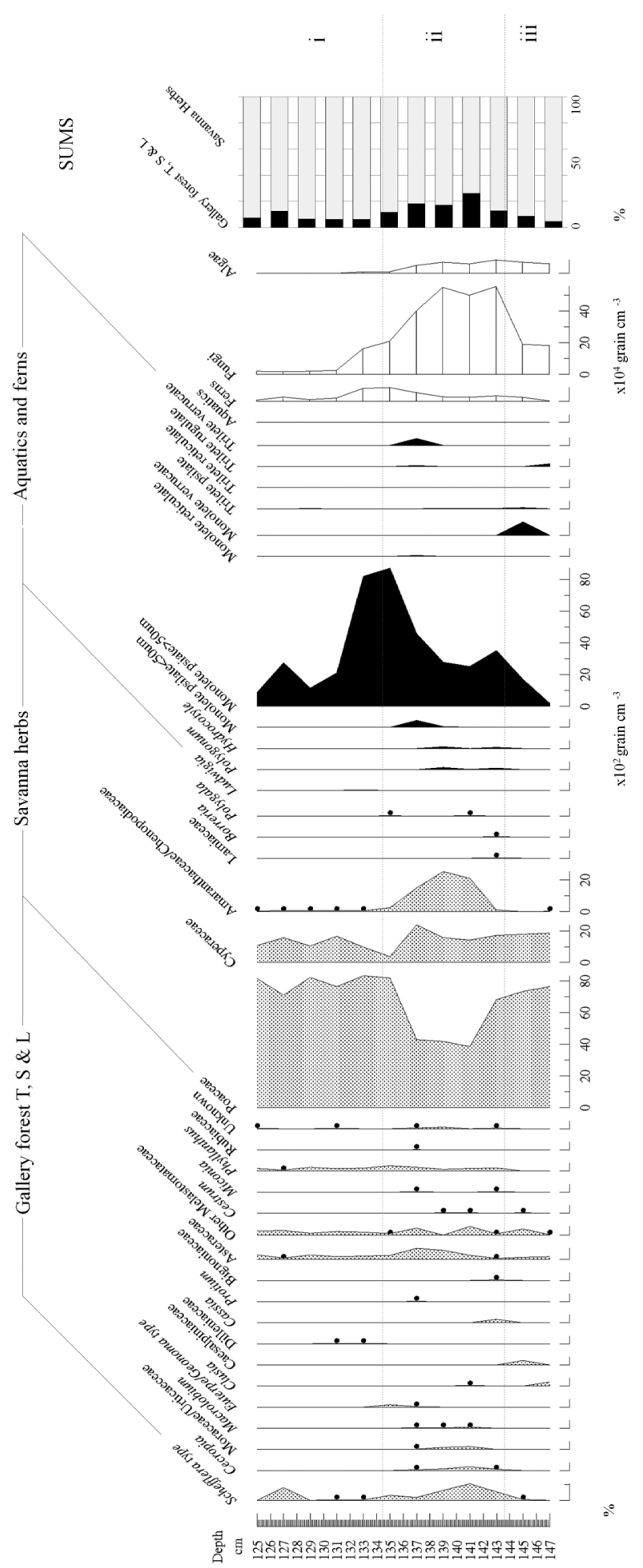

Figure 3 - Pollen and spores diagram of level A2 of Mapire core. Ecological groups: gallery forest trees $(\mathrm{T})$, shrubs $(\mathrm{S})$ and lianas $(\mathrm{L})$, and savanna herbs are expressed in percentage (\%), while aquatics, ferns, fungi and algae data in concentration units $\left(x 10^{2}\right.$ grains $\mathrm{cm}^{-3}$ for aquatics and ferns and $\times 10^{4}$ grains $\mathrm{cm}^{-3}$ for fungi, algae, total ferns and total aquatics). Dots mean values $<1 \%$. The total sum of ecological groups, aquatics and ferns, together with palynological zones "i", "ii" and "iii" are also shown delimited by a dotted line.

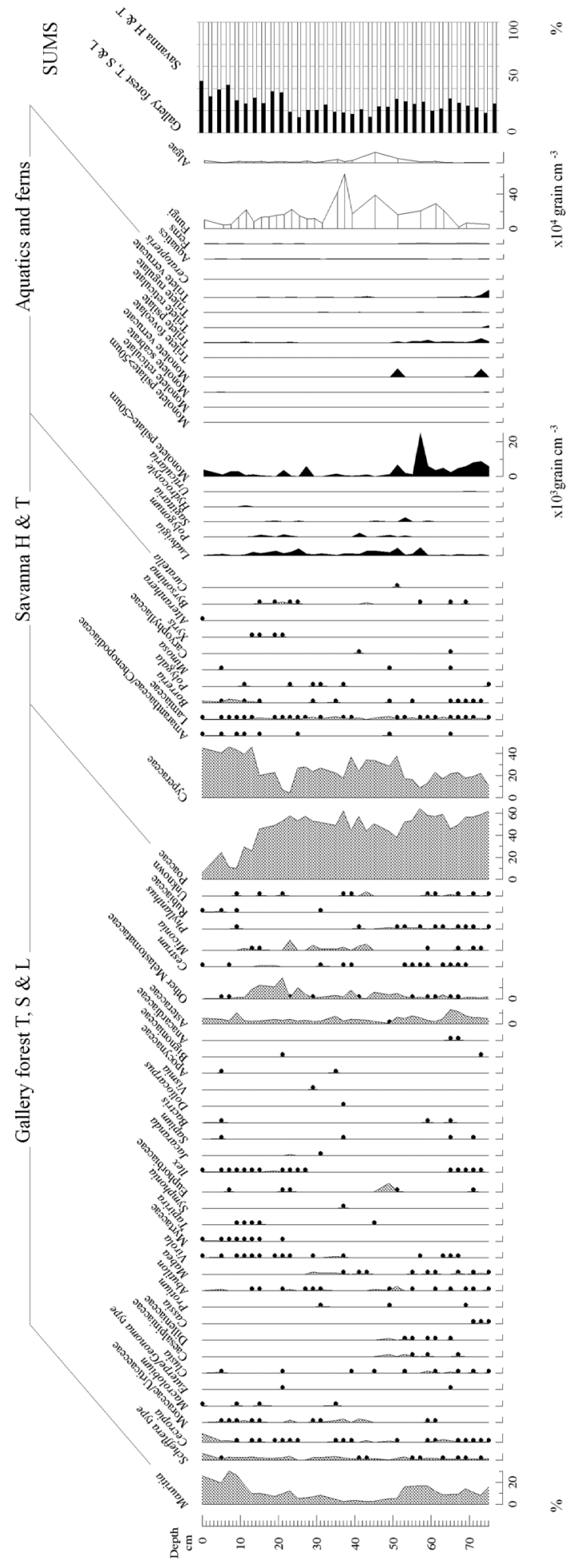

Figure 4 - Pollen and spores diagram of level A1 of Mapire core. Ecological groups: gallery forest trees $(\mathrm{T})$, shrubs $(\mathrm{S})$ and lianas $(\mathrm{L})$, and savanna herbs $(\mathrm{H})$ and trees $(\mathrm{T})$ are expressed in percentages (\%), while aquatics, ferns, fungi and algae data in concentration units $\left(\times 10^{3}\right.$ grains $\mathrm{cm}^{-3}$ for aquatics and ferns and $\times 10^{4}$ grains $\mathrm{cm}^{-3}$ for fungi, algae, total ferns and total aquatics). Dots mean values $<1 \%$. The total sum of ecological groups, aquatics and ferns are also shown. 
along the zone, and they were represented mainly by monolete psilate and some ornamented trilete similar to Lycopodium spores. However, pollen type richness dropped towards the end of the zone, which involved the disappearance of Cecropia, Moraceae/Urticaceae, Macrolobium and Euterpel Geonoma together with aquatics. Amarathaceae/Chenopodiaceae had a continuous record but decreased notably. Fungi and algae were around 550,000 and 85,000 grains $\mathrm{cm}^{-3}$ respectively, but decreased drastically towards the end of the zone. iii) A third zone from 131 to $125 \mathrm{~cm}$ (8,900 to 7,800 interpolated yr BP), where only Schefflera-type, Asteraceae, Melastomataceae and Phyllanthus remained in the gallery forest shrubs and trees group. Poaceae increased to 82\%, since Cyperaceae decreased to $10 \%$. Fern spores also disappeared, with the exception of monolete psilate. Fungi spores showed a strong depletion to 25,000 grains $\mathrm{cm}^{-3}$, while algae disappeared.

The pollen diagram of stratum A1 is shown in Figure 4. As can be seen Mauritia pollen had a continuous pollen record from 75 to $0 \mathrm{~cm}$ deep (2,220 interpolated yr BP to present), with abundance between 8 and 30\%. Additionally, pollen type richness was notably higher than that observed in Early Holocene sediments. Besides Mauritia, other genera which were absent from Early Holocene sediments occurred during the Late Holocene, for instance Abutilon, Mabea, Virola, Myrtaceae, Tapirira, Symphonia, Ilex, Jacaranda, Sapium and Bactris, among others, in the gallery forest shrubs, trees and lianas group. In the savanna herbs and trees group there were Mimosa, Alteranthera, Xyris and Byrsonima, and Sagittaria and Utricularia within the aquatics group. In general, the gallery forest elements were more abundant during the Late Holocene because of the presence of Mauritia, which had a mean percentage around 20\%. However, aside from Mauritia pollen, the gallery forest group had total percentages similar to those observed at zone "ii" of the Early Holocene section, but with a considerably higher level of richness. Also, total aquatics, fungi and algae concentrations were similar to those observed during the Early Holocene, but total fern influx was a half of that found on level A2.

\section{DISCUSSION}

\section{Vegetational and Climatic Trends Inferred from Mapire Core}

One of the most interesting results of our analysis was the absence of Mauritia pollen from the entire time spam encompassed by level A2 (Figure 2 and 3). The high concentration of fungi and algae, as well as the good representation of aquatics and ferns observed in general along A2 level, supports the idea that Early Holocene climate could have been humid, similar to that observed today, and was therefore suitable for Mauritia growth. Furthermore, some taxa that currently occur in Mauritia swamps such as Cecropia, Phyllanthus, Macrolobium, Euterpel Geonoma-type, Protium and Cestrum (Figure 3) were present during the Early Holocene despite the absence of Mauritia. The presence of such taxa in current Mauritia stands, growing on marshy soils, has been reported in flora inventories of palm swamps from Orinoco Llanos (Aristeguieta 1968; González 1987; Duno et al. 2007); and was also observed in modern pollen rain analyses on morichales in Gran Sabana (Rull 1991), and the Orinoco Delta (Müller 1959; Hofmann 2002). This might suggest that palm populations could have been reduced in the Orinoco Llanos during the Early Holocene as a response to the arid climates developed during the Late Pleistocene. This is a hypothesis largely supported by Rull (1998); however the low dispersion capacity of Mauritia pollen prevents us from drawing further conclusions from just a single record.

Instead of a Mauritia swamp, a Poaceae marsh surrounded by Asteraceae, Melastomataceae and Phyllanthus shrubs and trees covered the sampling site during the Early Holocene. This marsh existed from 10,225 to 9,800 yr BP (zone I, Figure 3), and shifted to a shallow lake between 9,800 and $8,900 \mathrm{yr} \mathrm{BP}$ (zone ii, Figure 3). Such interpretation is supported by the occurrence of pollen from floating plants (like Hydrocotyle and Polygonum), together with the increase of pollen from some elements typically found on lake shores, such as Cyperaceae and Amaranthaceae/Chenopodiaceae at zone ii (Figure 3). The increase of Cecropia, Asteraceae, Melastomataceae, Schefflera-type, Moraceae-Urticaceae, Phyllantus and Clusia, to more than $17 \%$ of the pollen sum, indicates likewise that this shallow lake was surrounded by shrubby vegetation, and even for a swampy gallery forest. The Poaceae marsh occurred again around 8,900 to $7,800 \mathrm{yr} \mathrm{BP}$, when total pollen, fungi and algae concentrations decreased progressively suggesting a gradient of humidity reduction (Figure 3), that eventually might have caused the absence of palynomorphs preservation observed in stratum B (Figure 2).

Level B showed in Figure 2, which followed the organic paleosol A2, also exhibited a characteristic mottled pattern probably caused by the differential oxidation of sediments, perhaps as a result of strong seasonal movements of the water table. Likewise, we hypothesize that the repeated drying out of sediments could have occurred in the study site during the Early to Mid-Holocene, evidencing an annual dry season that must have been longer and stronger than that observed today. Also, the fact that soil had been ventilated probably led to the oxidation of organic matter (and also pollen and spores) and in turn to the low SOC levels observed along this stratum (Figure 2). Nevertheless, another possible interpretation is that local changes associated with the River Mapire dynamic (changes in the river course or in the flooding regime) could have caused the observed sedimentological changes from 7.000 to 2.200 
yr. BP. This is however unlikely because changes occurred in coincidence with the beginning of an Early to Mid Holocene dry period that affected many localities at the Amazon and Orinoco Basins (see below) suggesting a response to regional climatic trends.

\section{Comparison with other records from Venezuela and Northern South America}

A couple of very detailed and analytic reviews about Quaternary climates of Venezuela were published by Rull $(1996,1999)$. Although 10 years has passed since these early works were published, these remain however updated, since very few additional paleoclimatological and/or paleoecological studies have been added until now. According to this author the Pleistocene/Holocene boundary in Venezuela has been settled to be around 10,000 yr BP, when the "Mucubaji" and "Paramo de Miranda" cold phases ended, and a warmer climate tended to stabilize. Also, a humid climate was observed in the Lake Valencia Basin around this date (Salgado-Labouriau 1980). This means that the record presented here started at the beginning of the Holocene, at the Pleistocene/Holocene boundary, when climate was recorded as humid, similar to present. This agrees with the main picture established for Venezuela and also for savanna areas located northward the ITCZ (Martin et al. 1997). In Mapire core, the Early Holocene humid period lasted from 10,225 yr BP to 7,800 interpolated yr BP. The onset of a wetter climate along the Pleistocene/Holocene transition also matches the dating of younger paleodunes of Western Orinoco Llanos around the year 11,000 BP (Roa 1979; Vaz and García-Miragaya 1989), which were apparently the last fossil dunes formed towards the end of the Pleistocene under arid conditions (location shown in Figure 1).

It is highlighted by Rull $(1996,1999)$ that most palynological records of Venezuela showed a cold and dry climatic phase in uplands and highlands (mainly at upland savannas of Guayana, Pantepui and Venezuelan Andes) around 6,000 to $4,000 \mathrm{yr}$ BP, which in some cases was extended until 3,500 or 3,000 yr BP. This phase, also recorded recently in new sites at Gran Sabana (Montoya et al. 2009), was recorded as a drier than present period in Mapire core between 7,800 and 2,200 yr BP at level B (Figure 2) when pollen preservation in sediments stopped, suggesting that sediments could have dried out repeatedly in the sampling site during a longer and stronger annual dry season. An arid phase of such magnitude was also evidenced by the occurrence of sodic alluvial soils studied by Vaz and García-Miragaya (1992) in the Central Orinoco Llanos (location shown in Figure 1), with Early to Mid-Holocene ages. Such Early to Mid-Holocene dry phase was also recorded at the Llanos Orientales of Colombia from 9,700-5,800 yr BP in Laguna Angel, Sardinas, Carimagua,
El Piñal and Chenevo (Behling and Hooghiemstra 1998; Behling and Hooghiemstra 1999; Berrío et al. 2002), and also in northwestern Brazil, and in general at the Amazon Basin, as is supported by Pessenda et al. (2001), and by Mayle and Power (2008), among others, encompassing the period between 8,000 to $4,000 \mathrm{yr}$ BP.

The establishment of the present climate in the Mapire core was settled around 2,200 yr BP, and hence the Early to Mid-Holocene dry phase was 1,000 to 3,000 yr longer than that recorded in other localities in Venezuela, Colombia and Brazil, where the present climate was established around 3,500; 4,000 or even 6,000 yr BP (Behling and Hooghiemstra 2001). It is possible that the Early-Mid Holocene aridity may have been longer in our study site due to its geographical position (in the northernmost edge of the ITCZ), but is more likely that time differences could be explained by the lack of accuracy in radiocarbon dating; specifically the dating of bulk samples where the decomposition of recent plant tissues, mainly roots, could be rejuvenating the organic matter. Errors associated with time-depth interpolations could be important in explaining the observed time lag as well.

\section{ACKNOWLEDGMENTS}

The authors are grateful to Susan Trumbore for giving facilities for radiocarbon dating. We also thank Maria Isabel Camejo for optic equipment facilities, and Maximiliano Bezada who organized the field work and supplied the vibracore sampler. Thanks to Valois González, José Luis Berroterán, Omar Linares, Valentí Rull, Juan Carlos Berrío, Otto Huber, Carlos Méndez, and two anonymous referees for critical comments of an early version of this manuscript. The authors are very grateful to the National Herbarium of Venezuela (VEN), for providing plant material for pollen determination, as much as to Milagros Rinaldi and Giovannina Orsini for their methodological advice. Thanks to Alfredo Sanson for reviewing of English grammar and style.

\section{REFERENCES}

Anderson, J.; Ingram, J. 1993. Tropical soil biology and fertility. First Edition.U.K., C.A.B. International, U.K. 171 pp.

Aristeguieta, L. 1968. Considerations of flora from morichales llaneros in north Orinoco. Acta Botánica Venezuelica, 3: 3-22 (In Spanish, with the Abstract in English).

Behling, H.; Hooghiemtra, H. 1998.Late Quaternary palaeoecolgy and palaeoclimatology from pollen records of the savannas of the Llanos Orientales in Colombia. Palaeogeography, Palaeoclimatology, Palaeoecology, 139: 251-267.

Behling, H.; Hooghiemstra, H. 1999. Environmental history of the Colombian savannas of the Llanos Orientales since the Last Glacial Maximum from lake records El Pinal and Carimagua. Journal of Paleolimnology, 22: 461-476. 
Behling, H.; Hooghiemtra, H. 2001.Neotropical savanna environments in space and time: late Quaternary interhemispheric comparisons. Interhemispheric climate linkages, Chapter 18. Academic Press, p 307-323.

Berrío, J.C.; Hooghiemstra, H.; Behling, H.; Botero, P.; Van der Borg, K. 2002. Late Quaternary savanna history of the Colombian Llanos Orientales from lagunas Chenevo and Mozambique; a transect synthesis. The Holocene, 12(1): 35-48.

Bush, M.; Weng, C. 2007. Introducing a new (freeware) tool for palynology. Journal of Biogeography, 34: 377-380.

Casanova, E. 1994. Introduction to soil science. Facultad de Agronomía, Universidad Central de Venezuela, Caracas, Venezuela. 337 pp. (Spanish).

Colinvaux, P.; De Oliveira, P.; Moreno, J. 1999. Amazon pollen manual and atlas. Harwood Academic Publishers. Amsterdam. $332 \mathrm{pp}$.

Colonello, G.; Ibáńez, C.; Ayarzaguena, J.; Lentino, M.; Paolillo, A.; Correa, R.; Valladares, L.; Teruel, H.; Pachano, O.; Ristorto, M.; Ameruoso, M. 1983. Ecological study in south Monagas and Anzoategui. Tomo I. Ecología Terrestre. Lagoven, Caracas, Venezuela. 81 pp. (In Spanish).

Duno, R.; Aymard, G.; Huber, O. Eds. 2007. Noted illustrated catalogue of vascular flora of Llanos de Venezuela. FUDENAFundación Empresas Polar-FIBV, Caracas. 738 pp. (In Spanish).

Faegri, K.; Iversen, J. 1981. Textbook of pollen analysis. Third Edition. Hafner Publishing, New York, U.S.A. 237 pp.

González, V. 1987. Morichales of llanos Orientales. An ecological approach. Serie Cuadernos CORPOVEN, Caracas, Venezuela. 35 pp. (In Spanish).

Herrera, L.; Urrego, L. 1996. Pollen atlas of useful and cultivated plants of Colombian Amazon. Tropenbos XI. Colombia. 402 pp. (In Spanish).

Hofmann, C. 2002. Pollen distribution in sub-Recent sedimentary environments of the Orinoco Delta (Venezuela) - an actuopaleobotanical study. Review of Palaeobotany and Palynology, 119: 191-217.

Hooghiemstra, H.; Van der Hammen, T. 1998. Neogene and Quaternary development of the neotropical rain forest: the forest refugia hypothesis, and a literature overview. Earth-Science Reviews, 44: 147-183.

Lanesky, D.E.; Logan, B.W.; Brown, R.G.; Hine, A.C. 1979. A new approach to portable vibracoring underwater and on land. Journal of Sedimentary Pretrology, 49: 654-657.

Leal, A.; Bilbao, B. In press. Cambios de vegetación durante el Holoceno Tardío en un morichal de los Llanos del Orinoco, Venezuela. Acta Botanica Venezuelica.

Martin, L.; Bertaux, J.; Corrége, T.; Ledru, M.P.; Mourguiart, P.; Sifeddine, A.; Soubiés, A.; Wirrman, D.; Suguio, K.; Turcq, B. 1997. Astronomical forcing of contrasting rainfall changes in tropical South America between 12400 and $8800 \mathrm{cal} \mathrm{yr} \mathrm{BP.}$ Quaternary Research, 47: 117-122.

Mayle, F.E.; Power, M.J. 2008. Impact of a drier Early-Mid-Holocene climate upon Amazonian forest.Philosophical Transactions of the Royal Society B, 363: 1829-1838.
Monasterio, M.; Sarmiento, G. 1970. Ecology of savannas from Tropical America: macroecological analysis in the llanos de Calabozo, Venezuela. Cuadernos Geográficos № 4, Facultad de Ciencias Forestales, Universidad de Los Andes, Mérida, Venezuela. 126 pp. (In Spanish).

Montoya, E.; Rull, V.; Nogué, S.; Díaz, W. 2009. Holocene paleoecology in the Gran Sabana, SE Venezuela: Preliminar analysis of pollen and moicrocarbons in Laguna Encantada. Collectanea Botanica, 28: 65-79. (In Spanish).

Muller, J. 1959. Palynology of recent Orinoco delta and shelf sediments: reports of the Orinoco Shelf Expedition. Micropaleontolgy, 5(1): 1-32.

Pessenda, L.C.R.; Boulet, R.; Aravena, R.; Rosolen, V.; Gouveia, S.E.M.; Ribeiro, A.S.; Lamotte, M. 2001. Origin and dynamic of soil organic matter and vegetation changes during the Holocene in a forest-savanna transition zone, Brazilian Amazon region. The Holocene, 11: 250-254.

Roa, P. 1979. Study of the dunes of llanos centrales de Venezuela: evidences of an arid climate. Acta Biológica Venezolana, 10(1): 19-49. (In Spanish, with Abstract in English).

Rull, V. 1991. Contribution to Pantepui and Gran Sabana paleoecology (Venezuelan Guayana): Climate, Biogeography and Ecology. ScientiaGuaianae, $N^{\circ}$ 2. (In Spanish).

Rull, V. 1996. Late Pleistocene and Holocene climates of Venezuela. Quaternary International, 31: 85-94.

Rull, V. 1998. Biogeographical and evolutionary considerations of Mauritia (Arecaceae), based on palynological evidence. Review of Palaeobotany and Palynology, 100: 109-122.

Rull, V. 1999. Paleoclimatology and sea-level history in Venezuela. New data, land-sea correlations, and proposals for future studies in the framework of the IGBP-PAGES Project. Interciencia, 24(2): 92-101.

Salgado-Labouriau, M.L. 1980. A pollen diagram of the PleistoceneHolocene boundary of lake Valencia, Venezuela. Review of Palaeobotany and Palynology, 30: 297-312.

Smith, D.G. 1984. Vibracoring fluvial and deltaic sediments: tips on improving penetration and recovery. Journal of Sedimentary Petrology, 54: 660-663.

Tschudy, R.H.; Tschudy, B.D. 1965. Modern fern spores of Rancho Grande, Venezuela. Acta Botánica Venezuelica, 1(1): 9-73.

Vaz, J.E.; García-Miragaya, J. 1989. Thermoluminescencedating of fossilsanddunes in Apure, Venezuela. Acta Cientifica Venezolana, 40 (1).

Vaz, J.E.; García-Miragaya, J. 1992. Thermoluminescence dating and chemistry of Quaternary sodic alluvial soils in the Venezuelan savanna. Catena, 19: 209-220.

Wille, M.; Hooghiemstra, H; Van Geel, V.; Behling, H.; Jong, A.; Van der Borg, K. 2003. Submillenium-scale migrations of the rainforest-savanna boundary in Colombia: $14 \mathrm{C}$ wiggle-matching and pollen analysis of core Las Margaritas. Palaeogeography, Palaeoclimatology, Palaeoecology, 193: 201-223.

Recebido em 09/08/2010

Aceito em 10/12/2010 